\title{
Assessment of the risk of major accidents occurring as a result of drilling and production operations in the sea areas based on the provisions of Directive 2013/30/EU
}

ABSTRACT. The offshore Oil \& Gas Industry is very important to the European Union economy. Therefore it must be properly monitored and protected, and legal regulations must be in place. Directive 2013/30/EU implemented on July 18, 2018 obliged EU Member States as well as operators and owners of oil and gas related activities in sea areas to implement solutions reducing the risk of major accidents, minor accidents and dangerous situations.

The purpose of the article is to identify all the possible hazards that may occur during oil and gas operations in marine areas and attempt to assess the risk along with providing effective responses in the event of its occurrence by preparing appropriate plans for responding to the situation. For the completion of the main purpose of the work the provisions of Directive 2013/30/EU of the European Parliament and of the Council of 12 June 2013 on safety of offshore oil and gas operations were presented and analyzed using the Hazard Identification method, the analysis of available reports prepared by the European Commission, classification bodies and own experience obtained while working in the offshore industry during searching, drilling and oil and gas production located under

$\bowtie$ Corresponding Author: Alicja Mrozowska; e-mail: a.mrozowska@amw.gdynia.pl

1 Comand and Naval Operation, Polish Naval Academy, Poland; ORCID iD: 0000-0001-9131-6366; e-mail: a.mrozowska@amw.gdynia.pl

2019. The Author(s). This is an open-access article distributed under the terms of the Creative Commons Attribution-ShareAlike International License (CC BY-SA 4.0, http://creativecommons.org/licenses/by-sa/4.0/), which permits use, distribution, and reproduction in any medium, provided that the Article is properly cited. 
the seabed at the Polish Economic Executive Zone. The study presents numerous analyses and comments, which were presented in the form of graphs and tables, based on international reports and own experience gained while working in an offshore company.

KEYWORDS: Directive 2013/30/EU, risk assessment, safety of oil and gas operations, external and internal emergency response plans

\section{Introduction}

The offshore Oil \& Gas Industry is very important to the European Union economy. Sixteen EU Member States are involved in offshore exploration and production. The activities are carried out in five of the EU's geographical areas (The North Sea, the Mediterranean Sea, the Baltic Sea, the Black Sea, and the Atlantic Ocean). Directive 2013/30/EU implemented on July 18, 2018 obliged EU Member States as well as operators and owners of oil and gas related activities in sea areas to implement solutions reducing the risk of major accidents, minor accidents and dangerous situations.

Due to the fact that an event occurred on the Gulf of Mexico in 2010, it was assumed that the probability of a catastrophe is unacceptably high.

On international and local grounds, a number of regulations and measures have been adopted to prevent a recurrent catastrophe. Focusing on solutions to protect oil and gas activities on the grounds of the EU, it can be concluded that member countries are the world leaders in preventing such accidents. There have been no major accident since the tragedy in the North Sea in 1988. It should be emphasized that production from the North Sea is responsible for $73 \%$ of oil and gas production for Western and Northern Europe. The EU introduces numerous regulations on the basis of the European Union, which are implemented on a specific Member State. They constitute a uniform standard in the field of conducted works in marine areas. Directive 2013/30/EU has become one of these solutions, which sets the minimum requirements in the field of major-accident prevention related to the operation of installations for exploration and the exploitation of energy resources in sea fields. From the perspective of time, from the implementation of requirements into force, they seem to be a good tool regulating the safety of operations, and thus protecting the marine environment from degradation due to the entry of dangerous substances resulting from exploration, drilling and oil drilling and natural gas. However, a full analysis of the effectiveness of the solutions implemented on its basis is not possible due to the short entry into force of its provisions.

In accordance with the provisions of the Directive, each owner, the operator and the licensee must identify the possibility of a major accident, dangerous events, potential threats to the state, and then assess the risk of its occurrence. After identifying the threats, one must take preventive measures and ensure proper risk management. The implementation of measures to reduce or 
maintain the risk at an acceptable level, as well as indication that risk control is carried out and ensured is fundamental to safety. An important element of ensuring broadly understood safety is continuous risk control through the systematic assessment of the effectiveness of preventive actions taken, as well as the implementation of contingency plans for a threat or potential threat.

The purpose of the article is to identify all possible threats (as well as major accidents) that may occur during oil and gas related activities in marine areas and an attempt to assess the risk of its occurrence, including ways to proceed in the event of its occurrence by preparing appropriate plans for responding to the situation according to Directive 2013/30/EU. The Hazard Identification method, the analysis of requirements of the provisions ISO 31000 - Risk Management, available reports prepared by the European Commission, classification societies and own experience gained while working in the offshore industry were used to achieve the assumed objective.

\section{Classification of hazards that may occur during oil and gas related activities in marine areas}

The classification of all events that may occur during drilling and mining works involves a wide range of elements that should be considered. These include: type of works, scope of works, place of their execution, conditions of works, parameters of the oil and gas fields, prevailing external conditions, properties of hydrocarbons, availability, risk of dangerous events. This is a difficult and multi-threaded task. In the first stage of the analysis, the author relies on the provisions of Directive 2013/30/EU, which in Article 2 provides the definition of major accidents in relation to offshore installations involved in conducting exploration, drilling and production works in sea areas within the scope of Directive: (...)

a) an incident involving an explosion, fire, loss of well control, or release of oil, gas or dangerous substances involving, or with a significant potential to cause, fatalities or serious personal injury,

(b) an incident leading to serious damage to the installation or connected infrastructure involving, or with a significant potential to cause, fatalities or serious personal injury,

(c) any other incident leading to fatalities or serious injury to five or more persons who are on the offshore installation where the source of danger occurs or who are engaged in an offshore oil and gas operation in connection with the installation or connected infrastructure; or(d) any major environmental incident resulting from incidents referred to in points (a), (b) and (c).

For the purposes of determining whether an incident constitutes a major accident under points (a), (b) or (d), an installation that is normally unattended shall be treated as if it were attended" (Directive 2013/30/UE).

However, in recognition of the author and experts of the members of the European Parliament, the classification needs to be more detailed in the identification of events that may occur, 
not only understood as serious failures. In recognition of the author, it should be extended to the specification of events, the occurrence of which may have other effects (smaller) for employees of the installation, the natural environment and property of significant value and influence the continuity of production (https://www.euractiv.com/section/energy).

The European Parliament also deplores the fact that incidents are defined as "serious" only if they cause death or serious injury, without reference to environmental consequences. Therefore, attention should be paid to other events in this area.

Table 1 specifies events that may occur during ongoing works, in accordance with the provisions of the Directive and other events that cause losses to people and of life, the environment and property, together with the causes, which in effect may be classified as serious failures due to a series of adverse events or other sudden events.

The above events can also be extended to other threats related to the off-shore industry (understood in the aspect of daily operational activities). These are hazards related to: towing, anchoring, setting and maintaining drilling platforms, floating warehouses and other auxiliary units at a given position (nuisance related to the operation of dynamic positioning systems DP and anchor systems) and cargo operations (transfer and acceptance) in the off-shore system and some sonar devices used in bottom research. Moreover, the nuisance for the marine ecosystem is the exploration and exploitation of underwater oil and gas, i.e. seismic surveys and associated forced underwater explosions and hydroacoustic waves generated by the air cannons.

The basic reasons for the occurrence of the above events are indicated along with the determination of their effects and impacts that may have on human health and life, the natural environment and infrastructure. The presented data constitutes a generalization giving an overview of the situation and highlighting events that may pose a threat to the broadly understood safety of work in marine areas. The author would like to emphasize that the detailed analyses are specific for a given case and constitute its operational property, and constantly evolve due to the variety of activities undertaken and external and internal factors affecting it. In the next part of the article, the manner of analysis of the risk will be determined along with the determination of the probability of its occurrence. Figure 1 shows the risk matrix. The risk matrix is a way of graphically show together consequence and the probability of accidents to provide an integrated description of risk.

The position of an event in the risk matrix should be interpreted as:

- An event in an acceptable zone means that the risk of the occurrence of the event is acceptable. There is no necessity to incorporate additional safety measures however the risk must be monitored.

$\checkmark$ An event in the ALARP zone (AS LOW AS REASONABLY PRACTICABLE) means that the risk should be monitored. The zone should be assessed by the ALARP measure. At the moment the risk is on the acceptable level and is controlled as low as reasonably practicable. Additional safety measures should be kept according to requirements and risk management.

$\checkmark$ An event in a not acceptable zone means that the risk is in the high level and must be reduced. Mitigating actions must be carried out to amend the activity. If there is no possibility to reduce the risk and incorporate safety measures, the activities will not be commenced. 
TABLE 1. Events that may occur during oil and gas production

TABELA 1. Zdarzenia, które mogą wystąpić podczas prac związanych z ropą i gazem

\begin{tabular}{|c|c|c|}
\hline No. & Type of threat & Causes of threat \\
\hline \multirow{4}{*}{1.} & \multirow{4}{*}{$\begin{array}{l}\text { Pollution of the sea, deterioration of } \\
\text { water quality and degradation of the } \\
\text { marine ecosystem. }\end{array}$} & $\begin{array}{l}\text { Oil and gas spills from installations on board and bottoms, pipelines, } \\
\text { storage tanks, reloading devices, during the operation of Ship to Ship } \\
\text { Transfer. }\end{array}$ \\
\hline & & Sinking cuttings to the bottom during drilling. \\
\hline & & Use and dumping of drilling fluids containing crude oil. \\
\hline & & $\begin{array}{l}\text { Production water discharges containing dangerous substances, chemi- } \\
\text { cals, pathogens, sewage contained in tanks and installations created } \\
\text { during the daily operation of the installation as during production } \\
\text { failures. }\end{array}$ \\
\hline \multirow[b]{2}{*}{2.} & \multirow{2}{*}{ Deterioration of air quality. } & $\begin{array}{l}\text { The emission of production gases and greenhouse gases generated } \\
\text { during the routine operation of production units into the atmosphere. }\end{array}$ \\
\hline & & $\begin{array}{l}\text { The emission of gases produced during normal operation to the atmo- } \\
\text { sphere and for the production of a non-flammable atmosphere in tanks. }\end{array}$ \\
\hline 3. & $\begin{array}{l}\text { Interference in the structure of the } \\
\text { bottom. }\end{array}$ & $\begin{array}{l}\text { Development of industrial infrastructure, drilling of bottom boreho- } \\
\text { les, testing of openings, putting up platforms, drilling rigs, floating } \\
\text { warehouses and other maritime structures, anchoring, laying of } \\
\text { bottom pipelines infrastructure consisting of pipelines, cables, trans- } \\
\text { mission installations. }\end{array}$ \\
\hline 4. & Noise. & $\begin{array}{l}\text { Coming from production and drilling equipment ensuring the current } \\
\text { operation of the installation, including cranes, fans, electro-mechani- } \\
\text { cal devices, drilling devices, conducting underwater works etc.). }\end{array}$ \\
\hline 5. & $\begin{array}{l}\text { Impact of movable elements in the } \\
\text { structure as well as the entire pro- } \\
\text { duction / drilling infrastructure }\end{array}$ & $\begin{array}{l}\text { During reloading work between the ship (supply vessel and installa- } \\
\text { tion) during the works carried out on the installation. }\end{array}$ \\
\hline 6. & Related to the transport of cargo. & $\begin{array}{l}\text { The collapse of cargoes, unsealing of packages during reloading, as } \\
\text { a result of breakdowns or mistakes made and equipment inefficient. }\end{array}$ \\
\hline 7. & $\begin{array}{l}\text { Fall from the height of more than } 2 \\
\mathrm{~m} \text { person working on the Installation } \\
\text { directly to the water or on the deck. }\end{array}$ & $\begin{array}{l}\text { Outboard work (routine, inefficient equipment, sudden event), in } \\
\text { work and transport baskets (resulting from a crane failure, handling } \\
\text { equipment, mistakes). }\end{array}$ \\
\hline 8. & $\begin{array}{l}\text { Psychoneurosis / concentration } \\
\text { disturbance }\end{array}$ & $\begin{array}{l}\text { Connected with working in often variable and dangerous conditions, } \\
\text { work and rest in the place of danger. }\end{array}$ \\
\hline 9. & Diseases of the installation crew & $\begin{array}{l}\text { Temperature changes occurring during works carried out in rooms } \\
\text { located outside and inside, air conditioning system in indoor rooms, } \\
\text { drafts. }\end{array}$ \\
\hline 10. & $\begin{array}{l}\text { Electromagnetic radiation (low and } \\
\text { high frequency) }\end{array}$ & $\begin{array}{l}\text { Talking over radio communication means. Being around transmitting } \\
\text { antennas. }\end{array}$ \\
\hline 11. & $\begin{array}{l}\text { Hit by falling elements. Pulling in } \\
\text { through moving parts, electric shock, } \\
\text { burns }\end{array}$ & $\begin{array}{l}\text { Tools and equipment used at work, dismantled elements, transported } \\
\text { loads, small elements of the platform equipment, impact by mounted } \\
\text { on ropes equipment in a well. }\end{array}$ \\
\hline 12. & $\begin{array}{l}\text { Connected to the transport of people } \\
\text { both by air and using a transport } \\
\text { basket }\end{array}$ & $\begin{array}{l}\text { Helicopter collapse, breakdown and related emergency ditching, } \\
\text { falling down from the basket. }\end{array}$ \\
\hline
\end{tabular}

Source: own study supported by (Rutkowski 2011) and own experience. 
Is the fact that the risk matrix ignores risk accumulation is a weakness. This comes from the fact that a risk matrix addresses one hazard one at a time. Thus, this may lead to a situation in which the potential accumulation of smaller risks resulting in a total unacceptable risk is not addressed. The risk must still be monitored and suitably managed.

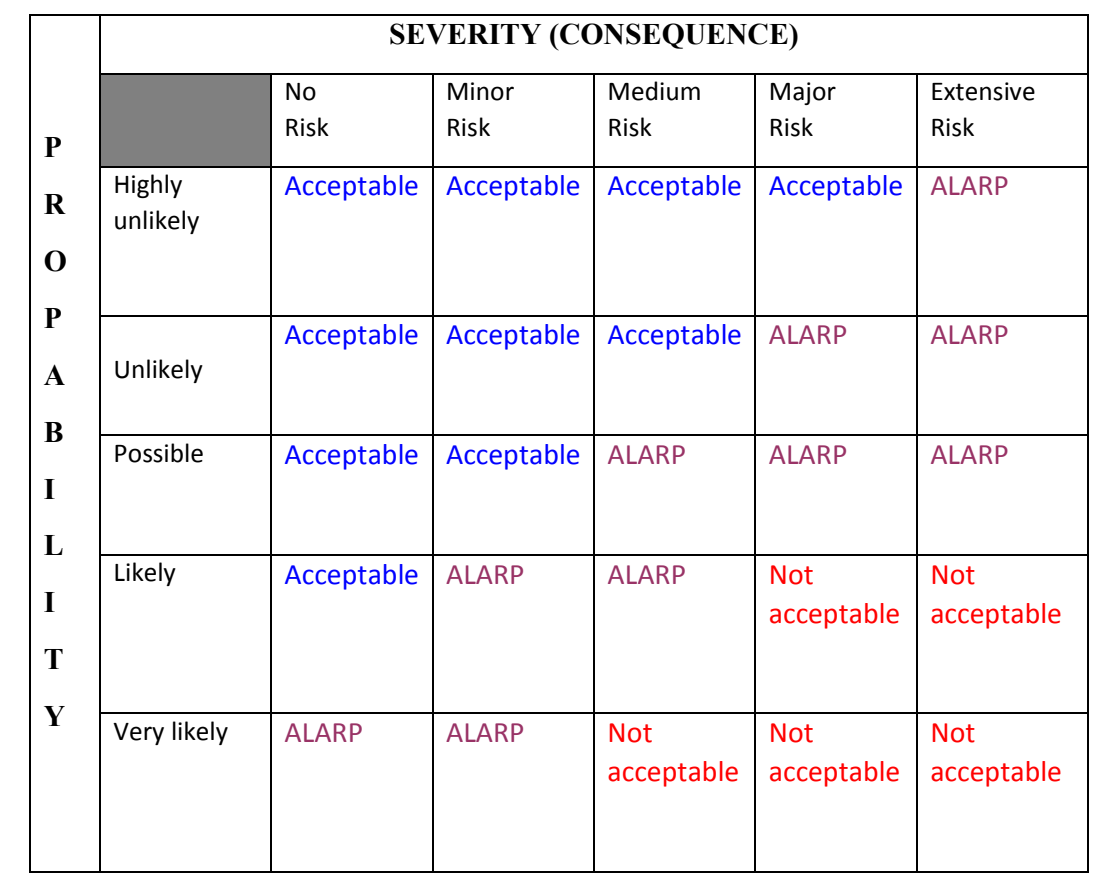

Fig. 1. Risk matrix

Sources: own study based on (Vamanu et al. 2016)

Rys. 1. Macierz ryzyka

Figure 2 presents the specific consequence and probability of their occurrence for people working on the installation, the events and losses caused in the natural environment and the probability of events and losses caused on the installation.

Taking the above into account, the author describes the impact for people working on the installation (fig. 3). This was extended by severity rating No. 1 .

If the risk level is too high and the implemented measures do not bring a reduction in risk, the work will not start until the risk is reduced. In this case, there is no permit to work (PTW) and the activities cannot be conducted. In connection with the above, an analysis and Job Safety Analysis (JSA) are carried out again.The JSA sequence consists of the following steps and is shown in Figure 4.

Operators should set themselves the main objective not to focus on reducing the effects of accidents and occupational diseases, but to eliminate and reduce occupational risks. One of the possibilities is to carry out JSA. 


\begin{tabular}{|c|c|c|c|c|c|c|c|c|c|}
\hline \multicolumn{4}{|c|}{ CONSEQUENCE } & \multicolumn{6}{|c|}{ PROBABILITY } \\
\hline & & & & 0 & A & B & C & $\mathrm{D}$ & $\mathrm{E}$ \\
\hline $\begin{array}{l}\text { Severity } \\
\text { rating }\end{array}$ & $\begin{array}{l}\text { People } \\
\text { (Health) }\end{array}$ & $\begin{array}{l}\text { Environment } \\
\text { (Pollution) }\end{array}$ & $\begin{array}{l}\text { Infrastructure } \\
\text { (Assets) }\end{array}$ & $\begin{array}{l}\text { Non- } \\
\text { credible to } \\
\text { occur }\end{array}$ & $\begin{array}{l}\text { Rare to } \\
\text { occurred }\end{array}$ & $\begin{array}{l}\text { Unlikely to } \\
\text { occur }\end{array}$ & $\begin{array}{l}\text { Credible to } \\
\text { occur }\end{array}$ & $\begin{array}{l}\text { Probable to } \\
\text { occur }\end{array}$ & $\begin{array}{l}\text { Frequency } \\
\text { to occur }\end{array}$ \\
\hline 0 & $\begin{array}{l}\text { Zero } \\
\text { injury }\end{array}$ & Zero effect & $\begin{array}{l}\text { Zero } \\
\text { damage }\end{array}$ & Acceptable & Acceptable & Acceptable & Acceptable & Acceptable & Acceptable \\
\hline 1 & $\begin{array}{l}\text { Slight } \\
\text { injury }\end{array}$ & Slight effect & $\begin{array}{l}\text { Slight } \\
\text { damage }\end{array}$ & Acceptable & Acceptable & Acceptable & Acceptable & Acceptable & ALARP \\
\hline 2 & $\begin{array}{l}\text { Minor } \\
\text { injury }\end{array}$ & Minor effect & $\begin{array}{l}\text { Minor } \\
\text { damage }\end{array}$ & Acceptable & Acceptable & Acceptable & ALARP & ALARP & ALARP \\
\hline 3 & $\begin{array}{l}\text { Major } \\
\text { injury }\end{array}$ & Local effect & $\begin{array}{l}\text { Local } \\
\text { damage }\end{array}$ & Acceptable & ALARP & ALARP & ALARP & ALARP & $\begin{array}{l}\text { Not } \\
\text { acceptable }\end{array}$ \\
\hline 4 & $\begin{array}{l}\text { Single } \\
\text { fatality }\end{array}$ & Major effect & $\begin{array}{l}\text { Major } \\
\text { damage }\end{array}$ & ALARP & ALARP & ALARP & $\begin{array}{l}\text { Not } \\
\text { acceptable }\end{array}$ & $\begin{array}{l}\text { Not } \\
\text { acceptable }\end{array}$ & $\begin{array}{l}\text { Not } \\
\text { acceptable }\end{array}$ \\
\hline 5 & $\begin{array}{l}\text { Above } 5 \\
\text { fatalities }\end{array}$ & $\begin{array}{l}\text { Massive } \\
\text { effect }\end{array}$ & $\begin{array}{l}\text { Extensive } \\
\text { damage }\end{array}$ & ALARP & ALARP & $\begin{array}{l}\text { Not } \\
\text { acceptable }\end{array}$ & $\begin{array}{l}\text { Not } \\
\text { acceptable }\end{array}$ & $\begin{array}{l}\text { Not } \\
\text { acceptable }\end{array}$ & $\begin{array}{l}\text { Not } \\
\text { acceptable }\end{array}$ \\
\hline
\end{tabular}

Fig. 2. Consequence and probability for people, environment and assets

Sources: own study based on (DNV report 2001; Vamanu et al. 2016)

Rys. 2. Efekt i prawdopodobieństwo zdarzenia dla ludzi, środowiska oraz infrastruktury

Moreover, the most important rules adopted should be based on:

Avoiding risks.

Assessment of the risk that cannot be avoided.

Prevention of risks at their source.

$\downarrow$ Adapting work to a single person.

\ Applying new technical solutions with available financial resources and economic justification.

$\checkmark$ Conduct a coherent and comprehensive preventive policy, including:

$\downarrow$ technical measures,

^ appropriate work organization,

$\downarrow$ creating appropriate working conditions,

$\downarrow$ social relations and the influence of factors related to the work environment.

$\downarrow$ giving priority to collective protection measures before personal protective equipment,

$\downarrow$ proper instructing and training of employees what the meeting is to serve - the so-called "Safety meeting" - organized at work especially dangerous or performed for the first time. 


\begin{tabular}{|c|c|c|c|c|}
\hline $\begin{array}{l}\text { Severity } \\
\text { rating }\end{array}$ & $\begin{array}{l}\text { People } \\
\text { (Health) }\end{array}$ & Description & Probability & Conclusions/ comments \\
\hline 0 & Zero injury & $\begin{array}{l}\text { There is no impact to the } \\
\text { health and life of people. }\end{array}$ & Acceptable & $\begin{array}{l}\text { Use basic safety measures } \\
\text { according to operational } \\
\text { instructions. Risk assessments } \\
\text { and JSA is not required. Risk } \\
\text { should be monitored. }\end{array}$ \\
\hline 1 & Slight injury & Slight injury & Acceptable & $\begin{array}{l}\text { Use only basic safety measures } \\
\text { according to operational } \\
\text { instructions. Risk assessments } \\
\text { and JSA is not required. Risk } \\
\text { should be monitored. }\end{array}$ \\
\hline 2 & Minor injury & $\begin{array}{l}\text { At most a single } \\
\text { injury } \text { minor } \\
\text { occupational illness. }\end{array}$ & ALARP & $\begin{array}{l}\text { Additional safety measures must } \\
\text { be taken. The risk must be } \\
\text { reduced to an acceptable level } \\
\text { and must be still monitored. }\end{array}$ \\
\hline 3 & Major injury & 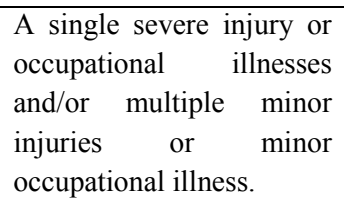 & ALARP & $\begin{array}{l}\text { Additional safety measures must } \\
\text { be taken. The risk must be } \\
\text { reduced to an acceptable level } \\
\text { and must be still monitored. }\end{array}$ \\
\hline 4 & Single fatality & $\begin{array}{lrr}\text { Single } & \text { death } \quad \text { or/and } \\
\text { multiple } & \text { severe injury or } \\
\text { severe } & \text { occupational } \\
\text { illnesses. } & \end{array}$ & $\begin{array}{c}\text { NOT } \\
\text { Acceptable }\end{array}$ & $\begin{array}{l}\text { The risk is high (on the not } \\
\text { acceptable level). The risk must } \\
\text { be reduced before tending to } \\
\text { activities. If there is no } \\
\text { possibility to reduce the risk, } \\
\text { the operation will not be carried } \\
\text { out. }\end{array}$ \\
\hline 5 & $\begin{array}{l}\text { Above } \\
\text { fatalities }\end{array}$ & $\begin{array}{ll}\text { Catastrophic } & \text { disaster } \\
\text { Multiple deaths. } & \end{array}$ & $\begin{array}{c}\text { NOT } \\
\text { Acceptable }\end{array}$ & $\begin{array}{l}\text { In this zone the risk is very high. } \\
\text { Risk reduction is very difficult } \\
\text { so the operation will probably } \\
\text { not be carried out unless the risk } \\
\text { is reduced. }\end{array}$ \\
\hline
\end{tabular}

Fig. 3. Impact for people working on the installation

Sources: own study supported by (DNV report 2001; Vamanu et al. 2016)

Rys. 3. Wpływ na ludzi pracujących na instalacji

As a result of identification of threats at workplaces as well as possible random events, it was found that the implementation of mining and drilling processes and the accompanying events that would result in the death of at least 5 people due to: identified technical hazards, staffing of individual services on the installation, is unlikely to happen in the offshore operations in the Baltic Sea region. 


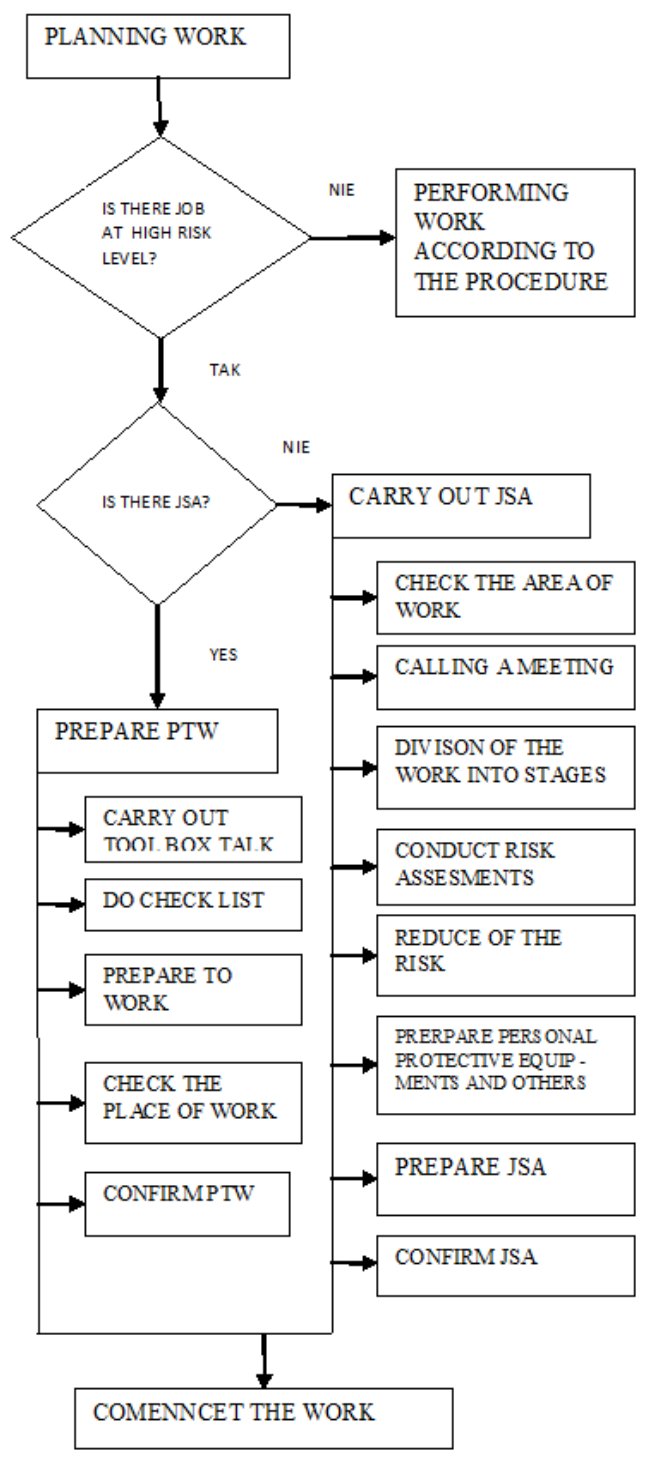

Fig. 4. JSA steps

Sources: (Mrozowska 2018)

Rys. 4. Etapy przeprowadzenia analizy bezpieczeństwa pracy

Figure 5 specifies the probability of the occurrence of events and losses caused in the natural environment. In the field of environmental protection, consideration should be given to the area of works carried out and the parameters of the deposit. In the case of deposits located in the Baltic Sea, any oil spill on the surface of the sea may be a loss for the natural environment. However, when analyzing the probability of an open eruption of the reservoir fluid, this is unlikely 
due to the low pressure in the reservoirs. In order to extract the material to the surface, the use of submersible pumps is necessary.

The probability of damage to the natural environment during drilling and production activities is thought to be low, taking the pressure prevailing in the oil and gas reservoir and the implemented the safety measures and procedures into account. The oil spills in the Baltic Sea reservoirs is is determined at 0.000004 (OIKS 2010). If the oil spill occurs, the main reasons will be failures or human factors.

\begin{tabular}{|c|c|c|c|c|}
\hline $\begin{array}{l}\text { Severity } \\
\text { rating }\end{array}$ & $\begin{array}{l}\text { People } \\
\text { (Health) }\end{array}$ & Description & Probability & Conclusions/ comments \\
\hline 0 & Zero injury & $\begin{array}{l}\text { There is no impact to the } \\
\text { health and life of people. }\end{array}$ & Acceptable & $\begin{array}{l}\text { Use basic safety measures } \\
\text { according to operational } \\
\text { instructions. Risk assessments } \\
\text { and JSA is not required. Risk } \\
\text { should be monitored. }\end{array}$ \\
\hline 1 & Slight injury & Slight injury & Acceptable & $\begin{array}{l}\text { Use only basic safety measures } \\
\text { according to operational } \\
\text { instructions. Risk assessments } \\
\text { and JSA is not required. Risk } \\
\text { should be monitored. }\end{array}$ \\
\hline 2 & Minor injury & $\begin{array}{l}\text { At most a single minor } \\
\text { injury } \text { or } \\
\text { occupational illness. }\end{array}$ & ALARP & $\begin{array}{l}\text { Additional safety measures must } \\
\text { be taken. The risk must be } \\
\text { reduced to an acceptable level } \\
\text { and must be still monitored. }\end{array}$ \\
\hline 3 & Major injury & $\begin{array}{l}\text { A single severe injury or } \\
\text { occupational illnesses } \\
\text { and/or multiple minor } \\
\text { injuries or minor } \\
\text { occupational illness. }\end{array}$ & ALARP & $\begin{array}{l}\text { Additional safety measures must } \\
\text { be taken. The risk must be } \\
\text { reduced to an acceptable level } \\
\text { and must be still monitored. }\end{array}$ \\
\hline 4 & Single fatality & $\begin{array}{lr}\text { Single } & \text { death } \quad \text { or/and } \\
\text { multiple } & \text { severe injury or } \\
\text { severe } & \text { occupational } \\
\text { illnesses. } & \end{array}$ & $\begin{array}{c}\text { NOT } \\
\text { Acceptable }\end{array}$ & $\begin{array}{l}\text { The risk is high (on the not } \\
\text { acceptable level). The risk must } \\
\text { be reduced before tending to } \\
\text { activities. If there is no } \\
\text { possibility to reduce the risk, } \\
\text { the operation will not be carried } \\
\text { out. }\end{array}$ \\
\hline 5 & $\begin{array}{l}\text { Above } \\
\text { fatalities }\end{array}$ & $\begin{array}{l}\text { Catastrophic disaster } \\
\text { Multiple deaths. }\end{array}$ & $\begin{array}{c}\text { NOT } \\
\text { Acceptable }\end{array}$ & $\begin{array}{l}\text { In this zone the risk is very high. } \\
\text { Risk reduction is very difficult } \\
\text { so the operation will probably } \\
\text { not be carried out unless the risk } \\
\text { is reduced. }\end{array}$ \\
\hline
\end{tabular}

Fig. 5. Impact on the environment

Sources: own study based on (DNV Report 2001 and provision of the Directive 2013/30/UE)

Rys. 5. Wpływ na środowisko 


\begin{tabular}{|c|c|c|c|c|}
\hline $\begin{array}{l}\text { Severity } \\
\text { rating }\end{array}$ & $\begin{array}{l}\text { Environment } \\
\text { (Pollution) }\end{array}$ & Description & Probability & Conclusions/ comments \\
\hline 0 & Zero effect & No pollution. & Acceptable & $\begin{array}{l}\text { The risk is on an acceptable } \\
\text { level. }\end{array}$ \\
\hline 1 & Slight effect & $\begin{array}{l}\text { Limited and occasional } \\
\text { impact. There is no visible } \\
\text { risk. }\end{array}$ & Acceptable & The risk is monitored. \\
\hline 2 & Minor effect & $\begin{array}{l}\text { Discharges that impact the } \\
\text { area but have transitory } \\
\text { effect, less than one week } \\
\text { for clean-up and one to } \\
\text { two years for natural } \\
\text { recovery. }\end{array}$ & ALARP & $\begin{array}{l}\text { Additional safety measures } \\
\text { must be implemented. The risk } \\
\text { still monitored. }\end{array}$ \\
\hline 3 & Local effect & $\begin{array}{l}\text { Discharges of limited } \\
\text { amount that affect the } \\
\text { nearby environment with } \\
\text { longer effect, short term } \\
\text { wider impact on water. } \\
\text { Less than one month for } \\
\text { clean-up and two to five } \\
\text { years for natural recovery. }\end{array}$ & ALARP & $\begin{array}{l}\text { Additional safety measures } \\
\text { must be implemented before } \\
\text { the activity starts. The risk } \\
\text { must be reduced to acceptable } \\
\text { level. The risk still monitored. }\end{array}$ \\
\hline 4 & Major effect & $\begin{array}{l}\text { Large discharges with a } \\
\text { persistent impact on the } \\
\text { environment with severe } \\
\text { and long lasting damage. } \\
\text { Widespread impact. } \\
\text { Five to ten years for } \\
\text { clean-up and more than } \\
\text { ten years for natural } \\
\text { recovery. }\end{array}$ & $\begin{array}{c}\text { NOT } \\
\text { Acceptable }\end{array}$ & $\begin{array}{l}\text { Additional safety measures } \\
\text { and forces must be prepared } \\
\text { for use as quickly as possible. } \\
\text { The risk must be reduced to an } \\
\text { acceptable level. Additional } \\
\text { safety measures must be } \\
\text { implemented. The risk must be } \\
\text { monitored and suitably } \\
\text { managed. }\end{array}$ \\
\hline 5 & Massive effect & $\begin{array}{l}\text { Large discharges with } \\
\text { persistent damage to the } \\
\text { environment. Long-term } \\
\text { and broader impact with } \\
\text { possible permanent loss of } \\
\text { species or ecosystem } \\
\text { functions. } \\
\text { More than five months for } \\
\text { clean-up and more than } \\
\text { ten years for natural } \\
\text { recovery. }\end{array}$ & $\begin{array}{c}\text { NOT } \\
\text { Acceptable }\end{array}$ & $\begin{array}{l}\text { If reducing the risk is not } \\
\text { possible, the operation must } \\
\text { not be carried out. }\end{array}$ \\
\hline
\end{tabular}

Fig. 5 cont.

Rys. 5 cd. 


\section{Implemented solutions at the organizational level as part of risk management}

Major failures/incidents during the exploitation of offshore energy resources are likely to have a significant negative impact on the marine and coastal environment. Therefore, it is important to reduce risk as much as possible to ensure reliable and effective mechanisms of action in state of emergency.

The provisions of the Directive 2013/30/EU in Article 3 and the Geological and Mining Law (Journal of Laws of 2017, No. 2126) Article 108 point $9 \mathrm{~b}$ discuss proper risk management (Geological and Mining Law Act 2019). Risks are assigned to those responsible for managing them, and to provide organizational and financial resources for effective risk management. In addition, they are required to constantly supervise the risk by: hazard identification, risk assessment, analysis of events related to risk, monitoring of risk minimization methods and, above all, undertaking organizational, technical and other activities to reduce risk and improve risk control. The component and, one can say, the basic aspect of safety is the involvement of all employees in the organization in monitoring the work environment and the early detection of threats. It is understood that every employee is responsible for risk management in the area of his/her competences, in particular for preventing threats in the scope of performed tasks, as well as reporting any events. Selected key risks that may be exposed during mining operations are presented below.

$\checkmark$ The risk of a threat of force majeure, resulting in a difficult implementation of the set objectives, caused by war or crisis.

$\downarrow$ The risk of uncontrolled flow to the hole, hole failure.

$\checkmark$ The risk of maritime collision.

$\checkmark$ The risk of fire/explosion.

$\checkmark$ The risk of the environmental contamination.

- The risk of an aircraft accident while transporting employees, resulting in loss of health and life.

The risk of limiting the availability of equipment and mining infrastructure due to limited durability or improper operation (Mrozowska 2018).

For certain risks, a number of solutions are introduced to reduce the risk to an acceptable level. If the risk level is too high and the measures implemented do not bring a reduction in risk, the activities will not start until the risk is reduced.

Moreover, the analysis of serious threats should take the risk to the environment, including the impact of climatic conditions and climate change on the long-term resistance of the installation into account. In the Baltic Sea region, the variability of weather conditions has been noticeable in the last ten years as being more rapid and unpredictable, which forces the frequency of inspections of underwater and surface water infrastructure to be increased.

Attention should also be paid to the risk of events affecting the employees of the installation, whose places are often at risk for serious injuries. Some of these injuries are the result of the 
hazardous nature of their work, but many more are caused by negligence. Many offshore injuries are the result of faulty or insufficient equipment. When equipment isn't properly maintained or isn't appropriate for the job at hand, it can lead to serious injuries to the workers operating the equipment and those working around it.

Mechanical failures can also be attributed to design and manufacturing defects. Workers on installations are surrounded by combustible materials. Fires and / or explosions can occur in all circumstances, as a result of failure, error committed by a human being or during adverse events, or a number of other events. The injuries that result from these incidents can be catastrophic, and often fatal (https://www.thelambertfirm.com).

Heavy machinery and support structures that break loose or aren't secured correctly have the potential to injure anyone on deck. Injuries due to exposure can also be related to the severe weather conditions offshore employees endure. Workers often labor for long hours in high temperatures, which can lead errors.

One of the solution to eliminate irregularities and errors at an early stage of work the awareness of hazards and motivate to detect irregularities, minimize the risk of accidents. In accordance with the provisions of Directive 2013/30/EU, the company must develop a motivational system for employees to minimize the risk of accidents and reward them for such attitudes.

\section{External and internal response plans as an effective tool to prevent major accidents and dealing with them}

To ensure the integration of ventures aimed at ensuring safe operations related to oil and gas, a number of projects are being implemented at the international and local level. Serious threats identified on the basis of paragraph No. 1 are included in internal and external emergency response plans to facilitate joint effective response in the event of a major accident.

For example, Article 29 of Directive 2013/30/EU, obliges Member States to develop external emergency response plans, including all installations related to oil and gas deposits in sea areas or connected infrastructure, as well as potentially affected areas under their jurisdiction. Member States shall define the role and financial commitment of licensees and operators in external emergency response plans.

External emergency response plans shall be developed by Member States in cooperation with the relevant operators and owners and, where applicable, operators and competent authority, and include the most up-to-date version of internal response plans in the case of a breakdown of existing or planned installations or combined infrastructure in the area covered an external emergency response plan.

"External response plan means a local, national or regional strategy to prevent or reduce the effects of major accidents related to offshore oil and gas operations using all resources available 
to the operator, as described in relevant internal plans emergency response, as well as using any additional means made available by Member States" (Directive 2013/30/EU).

The plan development process includes multilateral aspects and measures to achieve a high level of compatibility and interoperability of equipment and knowledge to be used in emergencies in all Member States in a given geographical region and, where appropriate, outside such a region.

In addition, entities conducting business activity are obliged to:

$\downarrow$ prepare and develop a list of equipment and activities used in the event of a breakdown that are compatible and interoperable throughout the geographical region.

$\checkmark$ checking its readiness for effective action in the event of major accidents in close cooperation with the relevant authorities of the Member States.

An example of such a solution in Poland is: the National Plan for Combating Threats and Pollution. It is developed by SAR's Director and approved by Ministry of the Marine Economy and Inland Navigation. The plan is agreed with the Maritime Administration, Ministry of the Interior and Administration, Ministry of the Environment, Ministry of the National Defense. The project of the National Plan for Combating Threats and Pollution is submitted for the approval by the SAR Council (The Act of Maritime Safety Article 121).

The elements in accordance with the provisions of the Regulation of the Ministry Councilthe organization and methods of combating threats and pollution at seas include:

1. Defining methods of alarming and informing about events that cause hazards or pollution.

2. Marine environment and contact points.

3. List and distribution of forces and measures that can be used for action to combat threats and pollution at sea.

4. The manner of conducting anti-pollution operations at sea, including special methods of conducting activities on waters identified as particularly vulnerable to pollution.

5. Tasks for entities cooperating with the SAR Service in actions to combat threats and pollution at sea.

6. Specification of units cooperating in combating threats and pollution at sea.

Moreover, once a year an exercise is organized, including SAR and Maritime Administration and Operator activities, during which coordination and checking of equipment operation, operating procedures and communication are practiced. Each time a report is prepared, which is discussed with all participants. New methods of combating pollution are also practiced, for example exercises in June 2018 in the Pomeranian Bay during which new forms of pollution collection are tested. More information read on the website (http://nowepomorze.pl).

In addition, any organization dealing in offshore oil and gas exploration must develop its internal response plans that are incorporated into the external response plan. The plans are developed on the basis of the provisions of Articles 14 and 28 set out in Directive 2013/30/EU. Article 14 specifies that the internal emergency response plan "means the plan developed by the operator or owner in accordance with the requirements of this Directive regarding measures to prevent or reduce the consequences of a major accident related to oil and gas activities in sea areas". 
In accordance with the provisions of Article 28, the internal plan must be developed taking the risk assessment of major accidents made during the preparation of the most recent report on major hazards into account. In addition, the plans should include an analysis of the effectiveness of response in the event of an oil spill.

Except provision Directive 2013/30/UE operators in the Polish Executive Zone must meet the requirements in accordance with paragraph 463 of the Ordinance of the Minister of Economy of April 25, 2014 on detailed requirements regarding the operation of mining plants extracting minerals from boreholes.

The plan includes a description of potential threats, rules of conduct and cooperation with support services, in particular with the Maritime Search and Rescue Service (SAR). The plan is agreed with the Maritime Administration and SAR and it is an integral part of the National Plan for Combating Marine Environment Danger and Pollution.

Information to be provided in the internal plan of response in the event of failure:

1. Identify the threats connected with oil and gas operation in the sea area

2. A description of operations and marine area with arrangements for limiting the risks to persons on the installation and the environment, including warnings;

3. List of contact names and positions of persons authorized to initiate emergency response procedures and the person directing the internal emergency response;

4. A description of the actions that will be taken to control conditions or events which could cause a major accident and to limit their consequences names and positions of persons authorized to initiate emergency response procedures and the person directing the internal emergency response;

5. A description of the equipment and the resources available, including for capping any potential spill name or position of the person with responsibility for liaising with the authority or authorities responsible for the external emergency response plan.

6. A description of all foreseeable conditions or events which could cause a major accident, as described in the report on major hazards to which the plan is attached.

7. In the case of combined operation, arrangements for coordinating escape, evacuation and rescue between the installations concerned, to secure a good prospect of survival for persons on the installations during a major accident;

8. An estimate of oil spill response effectiveness. Environmental conditions to be considered in this response analysis shall include: weather, including wind, visibility, precipitation and temperature; states, tides, and currents; presence of ice and debris, hours of daylight; and other known environmental conditions that might influence the efficiency of the response equipment or the overall effectiveness of a response effort.

9. Arrangements for providing early warning of a major accident to the authority or authorities responsible for initiating an external emergency response plan, the type of information which shall be contained in an initial warning and the arrangements for the provision of more detailed information as it becomes available.

10. Arrangements for training personnel in the duties they will be expected to carry out, and where necessary coordinating this with external emergency responders. 
11. Arrangements for coordinating internal emergency response with external emergency response.

12. Evidence of prior assessments of any chemicals used as dispersants that have been carried out to minimize public health implications and any further environmental damage.

\section{Response effectiveness in the event of a failure}

Oil spill response efficiency means the effectiveness of oil spill response systems based on an analysis of the frequency, duration and timing of environmental conditions that would prevent response. An assessment of the response effectiveness in the event of an oil spill should be expressed as a percentage of the time in which such conditions do not exist and should include a description of the operating restrictions imposed on the installations concerned as a result of this assessment.

The protective actions (minimizing the probability of occurrence of an event causing damage to the environment) before the occurrence of the spill include, above all:

$\checkmark$ applying safety in exploitation wells through the use of packers/deep safety valves,

$\downarrow$ supervision over the technical condition of technological equipment for oil production,

$\downarrow$ performing necessary repairs and protections in accordance with inspection and repair cards,

$\downarrow$ regular rounds of platform areas,

$\checkmark$ constant monitoring of the tightness of fittings and devices; performing pressure tests of new (replaced) fittings before putting into service,

$\downarrow$ periodic leak tests of the underwater transmission pipeline,

$\downarrow$ maintenance of risers and stays in a state of full efficiency and periodic observation of riders using an underwater camera,

$\downarrow$ environmental monitoring in the protection zone around the platforms,

$\downarrow$ maintenance of risers and underwater pipelines for oil exports in a state of full efficiency,

$\checkmark$ maintenance of floating hoses in full working order,

$\downarrow$ break-away valve on the line of floating hoses, which in case of breaking the hose line closes the flow in both directions,

$\checkmark$ maintenance of the mooring system buoy in full working order.

Intervention measures aimed at minimizing the effects of a potential event causing damage to the environment in the scope of oil spill include:

$\downarrow$ implementation of the plan to combat oil spills,

$\downarrow$ implementation of emergency response procedures,

$\downarrow$ appointing members of the crisis staff,

$\downarrow$ reporting to the competent authorities about the situation. 


\section{Conclusions and discussion}

The presented extensive analysis of major accidents showed a wide spectrum of threats that can be generated during the work. At the same time, they made us aware of the necessity of identifying risk and risk assessment as well as proper management through risk control and maintaining at an acceptable level. Serious failures undoubtedly exert or can have a serious impact on human health and marine and coastal ecosystems, which is why the main goal in the off-shore industry has been to develop and implement uniform standards for preventing and eliminating sources of offshore pollution and protecting marine areas from the negative effects of this activity.

Despite so many threats that accompany the processes of production, processing and transportation of crude oil in the open sea, this activity is properly regulated, properly managed and monitored by the number of implemented solution such as: International regulation, cooperation and external information and internal regulation, preparing technical, organization and safety measures. It should be emphasized that the progress of technology and the related implementation of new technologies and unified regulations have significantly contributed to the increase in the safety of oil and gas operations. In addition, the international cooperative and appropriate systems implemented ensure business management, enable continuous reporting of any events, and thus quick response in the case of an event. This ensures the effectiveness of response in the case of oil spills as well as the potential risk of its occurrence. It is also ensured by the implemented risk management systems by identifying risks, avoiding risk, assessing risk, implementing solutions in risk reduction, maintaining risk at an acceptable level, monitoring risk as well as immediate response in case of increasing the risk of an event. This applies to oil spills, threats to the life and health of people working on the installation as to those who may be on threated at the impact of an event, as well as losses in infrastructure and production.

The presented ocean of risk and impact on people, the environment indicated the scale of solutions. The examples of the magnitude of risk quoted above on the example of the Baltic Sea area showed that the risk is at a low acceptable level. The implemented solutions of Directive 2013/30/EU indicate the integration of multi-element forces and measures of technical, organizational and safety solutions, and thus form the foundation in ensuring local and transboundary safety. In recognition of the author, the topic is extremely important and will be developed in subsequent elaborations.

\section{References}

Directive 2013/30/EU of the European Parliament and of the council of 12 of June 2013 on safety of offshore oil and gas operations and amending Directive 2004/35/EC. L.178/66 official Journal of the EU 28.6.2013.

Det Norske Veritas for the health and safety executive offshore technology report 2001/063 London UK. 
Geological and Mining Law Act of 09 June 2011. Journal of Laws of 2017, item No 2126 the provisions of the Directive 2013/30/EU entered Poland (in Polish).

MAŁACZYŃSKI, M. 2010. Threats resulting from the exploitation of oil fields in the Baltic Sea shelf ( $\mathrm{Za}$ grożenia wynikające z eksploatacji podmorskich złóż ropy naftowej na Szelfie Morza Battyckiego) Published by „OIKOS” j.s.a, Gdańsk, November 2010 (in Polish).

Maritime safety Act 18 August 2011 (Dz.U. z 2016 r. item, No. 281) (in Polish).

MrozowsKA, A.2018. Review of the provisions of the European Parliament and of the Council Directive 2013/30/UE on safety of offshore oil and gas operations. Polityka Energetyczna - Energy Police Journal Vol. 21, Iss. 4.

MrozowSKA, A. and MrOzowSKI, P. 2019. How to improve safety on the offshore installations. TransNav Journal No. 2, Gdynia.

Oils spills drills on the baltic sea area oil (Ćwicza na baltyku zwalczanie rozlewów olejowych). [Online] http://nowepomorze.pl/pomorze-home-page/pomorze-wydarzenia-pomorskie-wiadomosci/2325-lotos-petrobaltic-cwiczy-na-baltyku.html [Accessed: 2019-10-25].

Offshore oil facing countdown to comply with new EU safety rules. [Online] https://www.euractiv.com/ section/energy/news/fri-offshore-oil-facing-countdown-to-comply-with-new-eu-safety-rules/ [Accessed: 2019-10-25].

Risk Management - Guidelines - ISO 31000:2018 published by ISO/TC 02/2018.

RUTKOWSKI, G. 2011. Safety problems in the offshore industry. Part 1. Oil spills and other types of threats registered in the off-shore sector (Problemy bezpieczeństwa w przemyśle offshore. Czesść 1. Rozlewy olejowe oraz inne rodzaje zagrożeń rejestrowane w sektorze off-shore). Maritme Academy Science Papers, No 26, Gdynia (in Polish).

Types of maritime accidents [Online] https://www.thelambertfirm.com/maritime-injury/types-offshore-accidents/ [Accessed: 2019-07-10].

VAmAnu, et al. 2016 - VAmAnU, B. NeCCi, A. TARANTOla, S. and Krausmann, E. 2016. Offshore risk assessment. An overview of methods and tools European Commision, Ispra.

Alicja MROZOWSKA

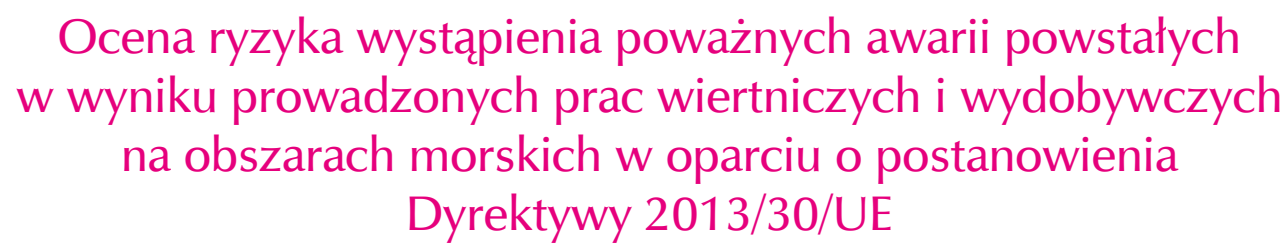

Streszczenie

Przemysł zajmujący się wydobywaniem oraz produkcją ropy i gazu na obszarach morskich jest ważny ze względów ekonomicznych dla Unii Europejskiej, dlatego działalność offshore musi być skutecznie uregulowana, monitorowania i zabezpieczana. Wprowadzona w życie Dyrektywa 2013/30/UE 18 lipca 2018 roku zobowiązała kraje członkowskie UE, jak i operatorów oraz właścicieli prowadzących działalność 
związaną z ropą i gazem na obszarach morskich do wdrożenia rozwiązań zmniejszających ryzyko wystąpienia poważnych awarii, wypadków i sytuacji niebezpiecznych.

Celem artykułu jest zidentyfikowanie wszelkich możliwych zagrożeń mogących wystąpić podczas prowadzonej działalności związanej z ropą i gazem na obszarach morskich oraz próba oceny ryzyka jego wystąpienia wraz z podaniem sposobów skutecznego reagowania w przypadku jego wystąpienia poprzez przygotowanie właściwych planów reagowania na zaistniałe sytuacje. Dla realizacji założonego celu pracy posłużono się przede wszystkim przedstawieniem i analizą postanowień Dyrektyw 2013/30/UE Parlamentu Europejskiego i Rady z dnia 12 czerwca 2013 roku w sprawie bezpieczeństwa działalności związanej ze złożami ropy naftowej i gazu ziemnego na obszarach morskich, metodą identyfikacji zagrożeń (HAZID), analizie dostępnych raportów opracowanych przez Komisję Europejską, towarzystwa klasyfikacyjnego oraz własnym doświadczeniu uzyskanym podczas pracy w polskim przedsiębiorstwie zajmującym się poszukiwaniem, wydobywaniem i produkcją ropy i gazu spod dna morskiego w polskiej Wyłącznej Strefie Ekonomicznej RP. Opracowanie przedstawia liczne analizy i wnioski umieszczone w tabelach i na rysunkach, opracowane na podstawie międzynarodowych raportów oraz własnym doświadczeniu.

SŁowA KLUCZOWE: Dyrektywa 2013/30/UE, analiza ryzyka, bezpieczeństwo wydobycia ropy i gazu, zewnętrzne i wewnętrzne plany reagowania na zagrożenia 
